\title{
Response Surface Methodology for Optimization of Protein Isolate Preparation from Custard Apple Seed Flour (Annona squmosa)
}

\author{
A.M. Vaidya*, D.C. Saxena and V.B. Somani \\ Department of Food Engineering and Technology, Sant longowal institute of Engineering and \\ Technology (Deemed University) - 148106, Longowal, Punjab, India \\ *Corresponding author
}

\section{A B S T R A C T}

\begin{tabular}{|c|}
\hline Keywords \\
\hline $\begin{array}{l}\text { Optimisation, } \\
\text { Response surface } \\
\text { methodology, } \\
\text { Central composite } \\
\text { rotatable design. }\end{array}$ \\
\hline Article Info \\
\hline $\begin{array}{l}\text { Accepted: } \\
28 \text { August } 2017 \\
\text { Available Online: } \\
\text { 10 September } 2017\end{array}$ \\
\hline
\end{tabular}

Keywords

Optimisation,

Response surface methodology, Central composite rotatable design

Article Info

Accepted:

Available Online

10 September 2017
In the present study workouts have been made to develop protein isolate from custard apple seed by using RSM (Response surface methodology). The variable considers percent $\mathrm{pH}, \mathrm{NaOH}$ concentration and Flour to solvent ratio $15 \mathrm{~g}$ of flour. As previous literature was not available preliminary trials were conducted to decide the approximate concentration of $\mathrm{pH}, \mathrm{NaOH}$ concentration and Flour to solvent ratio $15 \mathrm{~g}$ of flour. On the basis of trials ranges of variable decided which were 7 to $11 \%$ for $\mathrm{pH}, 0.6$ to 2 (Molar) $\mathrm{NaOH}$ concentration and 20 to $60 \%$ Flour to solvent ratio. Central composite rotatable design as a part of response surface methodology (RSM) was used to determine the optimum level of independent variable, which can produce protein isolate having maximum protein content, maximum protein yield. Optimum solution obtained by numerical optimization technique for protein isolate was $89.29 \%$ protein content and $51.58 \%$ protein yield, per $15 \mathrm{~g}$ of defatted flour. Corresponding to the optimum condition of independent variables for protein isolate the predicate value of protein content and protein yield, $86.29 \%$ and $51.58 \%$ respectively. The differences between predicted and actual values of optimized sample calculated were below $10 \%$ which is desirable. Finally optimized protein isolate was analyzed for proximate composition which showed better and acceptable result.

\section{Introduction}

Food industry produces as much of solids and liquid wastes, resulting from its production, preparation and consumption. These wastes pose potential disposal and pollution problems along with losses of valuable nutrients \& biomass. There is need to convert food processing wastes into useful products or even as raw material for other industries. The utilization from wastes of fruit and vegetable processing to be used as source of functional ingredients is a promising field (Schieber et al., 2001). Moreover, due to stringent national and international regulations, the waste management has become necessary. Food industry is going to look great challenges, such as to minimize wastes arising from processing operations and to utilize the byproducts and to reduce and treat the wastes along with sustainable production. Bioconversion of food processing residues is receiving increased attention regarding the fact that these residual matters represent possible measures and attract utilizable resource for conversion into useful products 
(Martin 1998). Custard apple belonging to Annonaceae family. The Annonaceae family contains adequate number of plants of economic significance because of their edible fruits. These crops represent the fruits of tropical America, Australia, Africa, Malaysia and India. In India the custard apple is a very sharp and short season fruit, lasting for about 3 months a year. Custard apple has three varieties Annona squamosa, Annona cherimola and Annona reticulata. The seeds are too hard that they may be swilling whole with no ill effects but the kernels are very toxic. Ancorine is an alkaloid extracted from custard apple seeds, which has insecticidal properties. The custard apple seeds contain $25.5 \%$ oil which is being used in soap and paint industries. The seed cake can be used as green manure for agriculture. The seeds, leaves and young fruits protective from insect due to insecticidal property and leaf juice used to inhibit lice (Morton 1987). More amounts of essential amino acids (phenylalanine, leucine, valine, threonine, isoleucine, methionine, tyrosine, histidine, cystine, arginine and lysine) were found in Annona squamosa seed. The percentage of sulphur-containing amino acids i.e methionine and cystine contains in Annona squamosa seed was $0.106 \mathrm{~g} / 100 \mathrm{~g}$ protein. The amino acids content of $\mathrm{A}$. squamosa seeds showed a high difference when compared to egg, sesame and broad bean amino acids (Mariod et al., 2010). Based on end user requirements, various extractions, fractionation and isolation procedures are followed. Generally, protein rich material extracted in alkaline solution followed by isoelectric precipitation is commonly followed for food applications (Sathe et al., 1984). Response surface methodology (RSM) is a statistical technique that helping us in getting information with less cost and short time. This technique relates with input and output parameters (Montgomery 1984). Its use leads to be rapid and efficient development of innovative products or processes. To optimize, extraction of protein isolate from custard apple seed using response surface methodology.

\section{Materials and Methods}

\section{Preparation of custard apple seed flour}

Whole fruit (matured) where procured from market with then removing seed from fruit. Seeds were then properly cleaned and dried. Then cleaned seeds were soaked in water for overnight $(12 \mathrm{hrs})$ at room temp to facilitate manual dehulling of seeds. After dehulling, seeds were splited and dried at $65^{\circ} \mathrm{C}$ until constant moisture content was attained. Drying was followed by grinding in grinder, sieving through 60 mesh size sieve. Finally prepared custard apple seed flour was packed in air tight polythene bag and stored at refrigerated condition until it was used for further processing is the protein isolate preparation.

\section{Preparation of defatted seed meal}

Seeds were dehulled, ground using hammer mill (M/S Narang Scientific Works, India), extracted with n-hexane three times (n-hexane ratio: flour 10:1, v/w), desolventized and ground again to pass through 72 mesh sieve to obtain fine powder, termed as deoiled meal and was stored at $201 \mathrm{C}$ till use. The experiment was carried out in duplicate.

\section{Preparation of custard apple seed protein isolate}

Custard apple seed meal was extracted with selected 20 combinations of independent variables such as $\mathrm{pH}$ (7-1), $\mathrm{NaOH}$ concentration, (0.6-2), Flour to solvent ratio (20-60). Defatted custard apple seed flour (10 g) was extracted with deionized water in a stirred glass vessel at constant temperature. 
The slurry was centrifuged (Hettich, Germany) at $2700 \mathrm{~g}$ for $20 \mathrm{~min}$, the supernatant was collected and the soluble protein content was determined according to the method of (Lowry et al., 1951). All the experiments were carried out in triplicate.

\section{Proximate analysis}

Moisture, crude fat, crude protein, ash content were determined according to method of (AOAC 1997)

\section{Experimental design and statistical analysis}

Response surface methodology (RSM) explores the relationships between several explanatory variables and one or more response variables. The method was introduced by (Box and Wilson, 1951). Response surface methodology (RSM) was adopted in the experimental design as it emphasizes the modeling and analysis of the problem in which the response of interest is influenced by several variables and the objective is to optimize this response (Montgomery, 2001).The Design matrix for effect of process variables on dependent variables is shown in table 1 . Variables $\mathrm{pH}$ (A), $\mathrm{NaOH}$ concentration (B) and solvent to Flour ratio (C) in the custard apple seed protein isolation process was investigated. Each variable was coded at five levels: 1.68 , $-1,0,+1,+1.68$ is shown in table 2 . The variables were coded according to the following equation: $\mathrm{X}_{\mathrm{i}}=\left(\mathrm{X}_{\mathrm{i}}-\overline{\mathrm{X}}_{\mathrm{i}}\right) / \Delta \mathrm{X}_{\mathrm{i}}$ (1) where $\mathrm{Xi}$ is the dimensionless value of an independent variable, $x i$ is the real value of an independent variable, $x \overline{1}$ is the real value of an independent variable at the center point, $\Delta \mathrm{xi}$ is the step change. A central composite design (CCRD) was arranged to allow for fitting of second-order model (Nakai, Li- Chen, \& Dou, 2006). The star points were added to the factorial design to provide for estimation of curvature of the model.

\section{Y $\beta_{0}+\beta_{1} A+\beta_{2} B+\beta_{3} C+\beta_{11} A^{2}+\beta_{22} B^{2}+\beta_{33} C^{2}+\beta_{12} A$ $\mathrm{B}+\beta_{13} \mathrm{AC}+\beta_{23} \mathrm{BC}+\varepsilon$}

The coefficients of the polynomial were represented by $\beta_{0}$ (constant), $\beta_{1}, \beta_{2}, \beta_{3}$ (linear terms); $\beta_{12}, \beta_{13}, \beta_{23}$, (interaction effects); $\beta_{11}$, $\beta_{22}, \beta_{33}$ (quadratic effects); and $\varepsilon$ (random error). Data were modelled by multiple regression analysis and the statistical significance of the terms was examined by analysis of variance for each response. The objective in the optimization process was to find a common value for the dependent variables; thus we used a numerical multiresponse optimization technique was applied (Park et al., 1993) to determine the optimum combination of $\mathrm{pH}, \mathrm{NaOH}$ concentration, flour to solvent ratio for the production of protein isolate. The assumptions were to develop a product which would have maximum score in sensory acceptability so as to get market acceptability, maximum protein Content, and maximum protein yield. Therefore, among responses, these parameters were attempted to be maintained whereas other parameters were kept within range. Under these criteria, the uncoded optimum operating conditions for development of protein isolate $\mathrm{pH}, \mathrm{NaOH}$ concentration, flour to solvent ratio where $10.40,0.60$ (Molar),40.96\%. The responses predicted by the design expart-6 software for these optimum process conditions resulted protein content $89.35 \%$ and protein yield 51.58.

\section{Results and Discussion}

\section{Proximate composition of flour prepared from custard apple seed}

The proximate analysis of defatted flour prepared from custard apple seed is shown in table 3. The protein content of custard apple seed flour $18 \%$ was higher than bitter melon seed flour $11.8 \%$. Higher protein of these 
flours can explore the possibility for its use (Ngam and Tan, 2009).

\section{Fitting the models}

Custard apple seed flour was extracted for its protein following 20 combinations of three independent variables $(\mathrm{pH}, \mathrm{NaOH}$ concentration, flour to solvent ratio). Results revealed that the experimental protein content 46.54 to 90.03 and protein yield varied from 12 to $57.12 \mathrm{~g}$ soluble protein/15 g custard apple seed flour. (Quanhang and Caili 2005) found that the protein yield was 2.77-7.86 $\mathrm{g}$ protein/100 g germinant pumpkin seeds. (Liadakis et al., 1995) extracted 43.9-57.3\% of the proteins contained in tomato seed meal. The application of RSM yields the following regression equation, which is an empirical relationship between protein content and protein yield and the test variable in coded units, as given in the following equation. The quadratic model obtained from regression analysis for protein content in terms of coded levels of the variables was as follows:

Protein Content $=81.02+5.99 \mathrm{~A}-5.13 \mathrm{~B}-$ $0.96 C-8.91 A^{2}-5.06 B^{2}-4.83 C^{2}-7.76 A B-$ $1.64 \mathrm{AC}+5.22 \mathrm{BC}$

Eq. (3.2) showed that protein content of isolate had highly significant $(\mathrm{p}<0.05)$ positive linear effect on $\mathrm{pH}(\mathrm{A})$ and negative linear effect of concentration (B) and flour to solvent ratio. The quadratic terms of $\mathrm{pH}\left(\mathrm{A}^{2}\right)$, concentration $\left(\mathrm{B}^{2}\right)$ and flour to solvent ratio $\left(C^{2}\right)$ was significant $(\mathrm{p}<0.05)$ having negative quadratic effect, predicting the concave shaped variation on the protein content.

The interaction terms of $-\mathrm{pH}$ and Concentration (AB) had negative significant effect and Concentration and flour to solvent ratio (BC) had positive significant effect.The interaction terms $\mathrm{pH}$ and flour to solvent ratio negative significant.

$$
\begin{array}{llr}
\text { Protein yield }=47.21 & +13.50199 \mathrm{~A}- \\
16.47820 \mathrm{~B}+0.22471 & \mathrm{C} & -0.97467 \mathrm{~A}^{2} \\
+8.90944 \mathrm{~B}^{2}-0.020212 \mathrm{C}^{2} & & -1.39464 \mathrm{AB} \\
+0.16938 \mathrm{AC}+0.13964 \mathrm{BC} & &
\end{array}
$$

Eq (3.3) showed that protein yield of isolate had highly significant $(\mathrm{P}<0.05)$ positive linear effect on $\mathrm{pH}$ (A) and negative linear effect of $\mathrm{NaOH}$ concentration (B). Other linear term is not significant $(\mathrm{P}>0.05)$.

The quadratic terms of $\mathrm{pH}\left(\mathrm{A}^{2}\right)$, and flour to solvent ratio $\left(\mathrm{C}^{2}\right)$ was significant $(\mathrm{P}<0.05)$ having negative quadratic effect, and $\mathrm{NaOH}$ concentration $\left(\mathrm{B}^{2)}\right.$ having positive quadratic effect. Predicting the concave shaped variation on the protein yield. The interaction terms of $\mathrm{pH}$ and $\mathrm{NaOH}$ Concentration (AB) had negative significant effect, $\mathrm{NaOH}$ concentration and flour to solvent ratio (BC) had positive significant effect and also $\mathrm{pH}$ and flour to solvent ratio (AC) having positive effect.

The model terms $\mathrm{A}, \mathrm{C}, \mathrm{A}^{2,} \mathrm{~B}^{2,} \mathrm{C}^{2,} \mathrm{AC}, \mathrm{AB}$ were found significant. F-values for linear terms of $\mathrm{pH}(\mathrm{A})$ and flour to solvent ratio (C) were 30.56 and 397.58 respectively and $p$ value less than 0.2689 , validating a not significant model term.

F-value for square term of $\mathrm{pH}\left(\mathrm{A}^{2}\right), \mathrm{NaOH}$ concentration $\left(\mathrm{B}^{2}\right)$, and flour to solvent ratio $\left(C^{2}\right) \quad$ were $147.18,201.82$ and 628.65 respectively.

\section{Optimization of the process}

The 3D surface plots were drawn to illustrate the main and interactive effects of the independent variables on the dependent one. These graphs were obtained by fixing two variables at coded zero level while varying the remaining two variables and predicting the response variable (protein content, and protein yield). 
Effect of process variables on protein content

Figure 1 showed the effect of $\mathrm{pH}$ and $\mathrm{NaOH}$ concentration on the protein content. Coefficient of $\mathrm{pH}$ (A) was shown positive effect on protein content. In this study linear terms of $\mathrm{pH}(\mathrm{A})$ and $\mathrm{NaOH}$ concentration (B) had significant and non-significant effect at $5 \%$ level of significance $(\mathrm{p}<0.05)$ respectively.

The quadratic terms of $\mathrm{pH}\left(\mathrm{A}^{2}\right), \mathrm{NaOH}$ concentration $\left(\mathrm{B}^{2}\right)$ and flour to solvent ratio $\left(C^{2}\right)$ was significant $(p<0.05)$ having the negative quadratic effect, Predicting the concave shaped variation on the protein content. However, coefficient of concentration (B) was not so much effective which showed negative effect on the protein content.

\section{Effect of independent variable $\mathrm{pH}$ and} flour to solvent ratio on protein content

Coefficient of $\mathrm{pH}$ (A) was shown positive effect on protein content In this study linear terms of $\mathrm{pH}(\mathrm{A})$ andflour to solvent ratio (C) had significant and non-significant effect at $5 \%$ level of significance $(\mathrm{p}<0.05)$ respectively. The quadratic terms of $\mathrm{pH}\left(\mathrm{A}^{2}\right)$, $\mathrm{NaOH}$ concentration $\left(\mathrm{B}^{2}\right)$ and flour to solvent ratio $\left(\mathrm{C}^{2}\right)$ was significant $(\mathrm{P}<0.05)$ having negative quadratic effect, predicting the concave shaped variation on the protein content. Coefficient of flour to solvent ratio (C) was not so much effective which showed negative effect on the protein content (Fig. 2).

Table.1 Design matrix for effect of process variables on dependent variables

\begin{tabular}{|l|c|c|c|l|l|}
\hline Run & $\mathrm{pH}$ & $\mathrm{NaOH}$ concentration & Flour to solvent ration & Protein content & Protein yield \\
\hline 1 & 7 & 0.6 & 20 & 56.01 & 37.73 \\
\hline 2 & 11 & 0.6 & 20 & 90.03 & 29.48 \\
\hline 3 & 7 & 2 & 20 & 54.05 & 38.23 \\
\hline 4 & 11 & 2 & 20 & 50.32 & 25.01 \\
\hline 5 & 7 & 0.6 & 60 & 50.13 & 34.89 \\
\hline 6 & 11 & 0.6 & 60 & 70.87 & 34.89 \\
\hline 7 & 7 & 2 & 60 & 62.32 & 38.73 \\
\hline 8 & 11 & 2 & 60 & 58.75 & 54.33 \\
\hline 9 & 5.63 & 1.3 & 40 & 46.54 & 30.97 \\
\hline 10 & 12.36 & 1.3 & 40 & 66.98 & 37.05 \\
\hline 11 & 9 & 0.12 & 40 & 76.12 & 57.52 \\
\hline 12 & 9 & 2.47 & 40 & 59.19 & 57.25 \\
\hline 13 & 9 & 1.3 & 6.63 & 69.74 & 12 \\
\hline 14 & 9 & 1.3 & 73.63 & 66.87 & 33.05 \\
\hline 15 & 9 & 1.3 & 40 & 81.37 & 46.57 \\
\hline 16 & 9 & 1.3 & 40 & 79.02 & 44.23 \\
\hline
\end{tabular}

Table.2 Range and levels of the independent variables in a CCRD design

\begin{tabular}{|l|c|c|c|c|c|c|}
\hline Independent Variables & Symbol & \multicolumn{5}{|c|}{ Levels in coded form } \\
\hline & Uncoded & $\mathbf{- 1 . 6 8}$ & $\mathbf{- 1}$ & $\mathbf{0}$ & $\mathbf{+ 1}$ & $\mathbf{+ 1 . 6 8}$ \\
\hline pH & $\mathrm{A}$ & 5.64 & 7 & 9 & 11 & 12.36 \\
\hline NaOH Concentration & $\mathrm{B}$ & 0.12 & 0.6 & 1.3 & 2 & 2.48 \\
\hline Flour to solvent ratio & $\mathrm{C}$ & 6.36 & 20 & 40 & 60 & 73.64 \\
\hline
\end{tabular}


Table.3 Proximate analysis of custard apple seed flour

\begin{tabular}{|l|l|l|}
\hline Sr.no & Parameters $(\%)$ & Results \\
\hline 1 & Moisture & $2.9 \pm 0.28$ \\
\hline 2 & Total Carbohydrates & $48.18 \pm 0.61$ \\
\hline 3 & Protein & $18.05 \pm 0.27$ \\
\hline 4 & Fat & $22 \pm 0.5$ \\
\hline 5 & Ash & $2 \pm 0.24$ \\
\hline 6 & Crude Fiber & $11 \pm 0.26$ \\
\hline
\end{tabular}

Values are means \pm standard deviation of triplicate determination.

Fig.1 Effect of independent variable $\mathrm{pH}$ and concentration on protein content

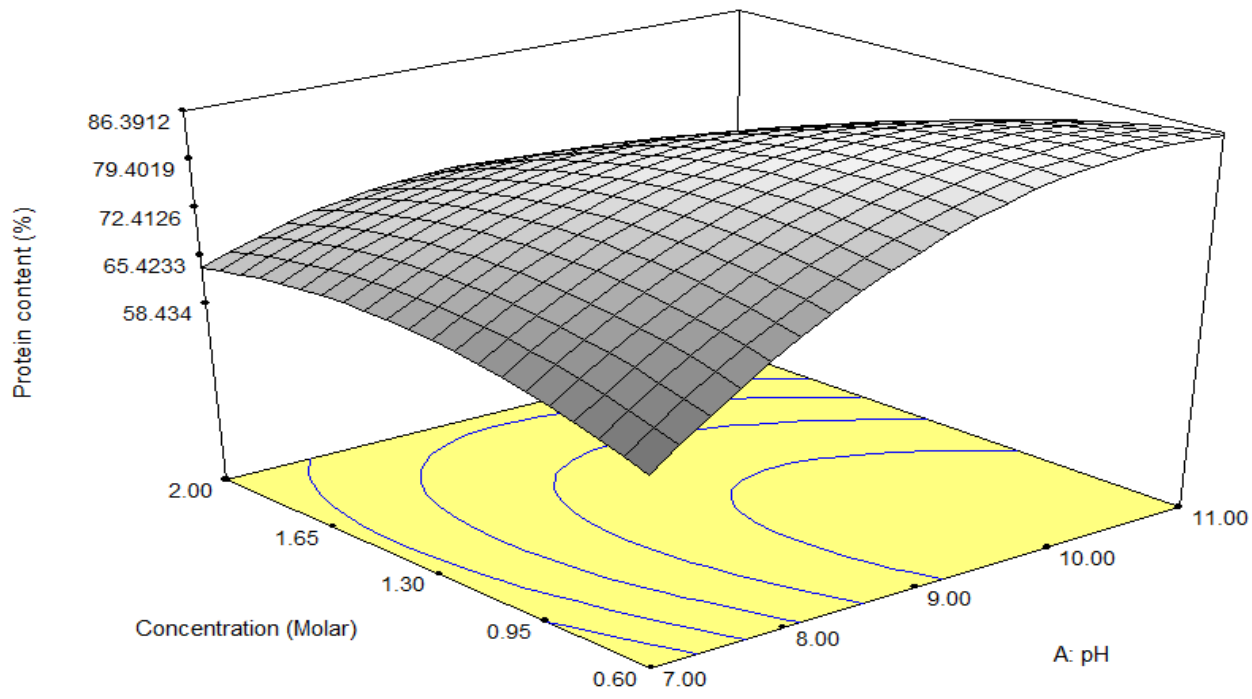

Fig.2 Effect of independent variable $\mathrm{pH}$ and flour to solvent ratio on protein content

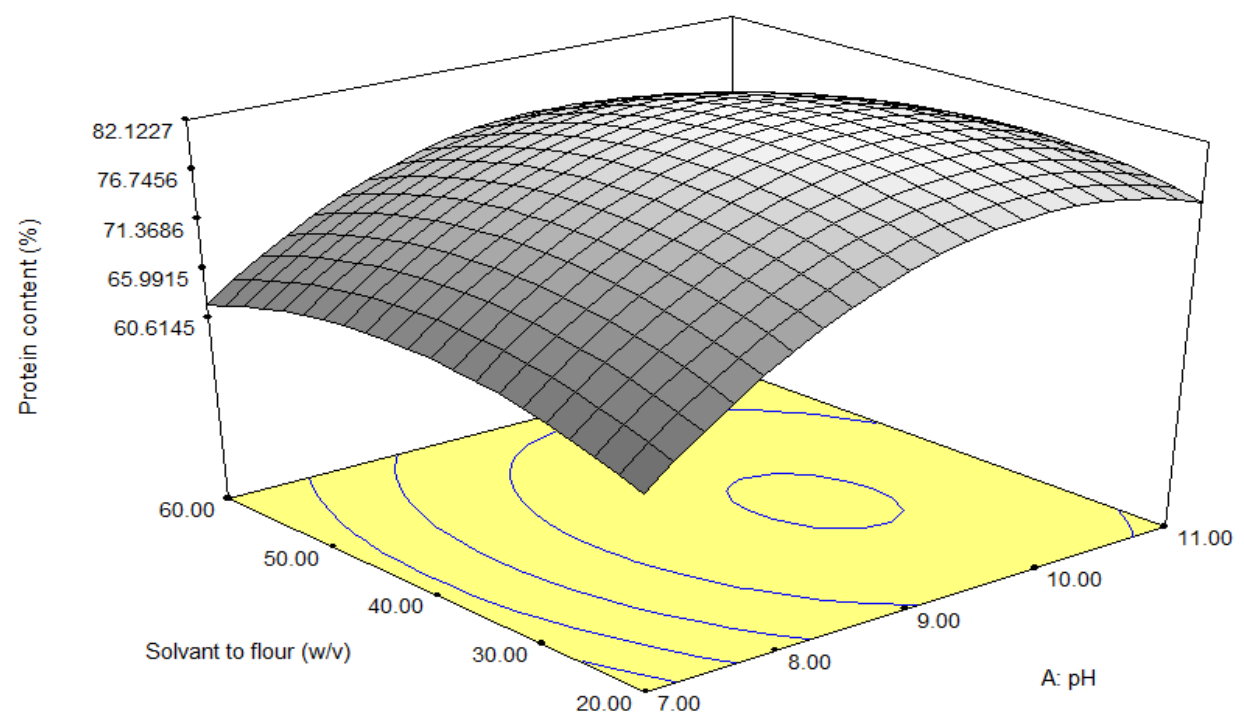


Fig.3 Effect of independent variable $\mathrm{NaOH}$ concentration and flour to Solvent ratio on protein content

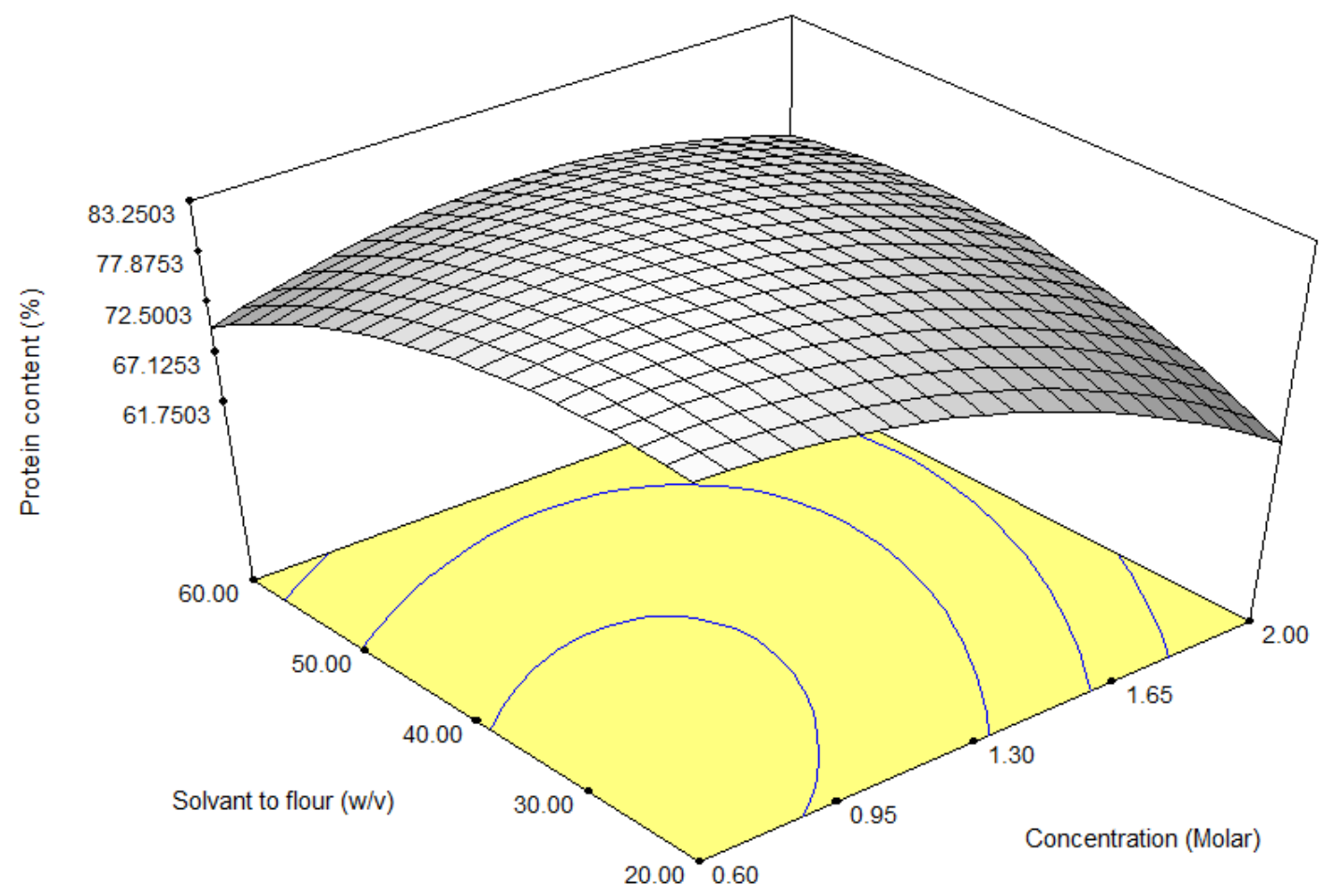

Fig.4 Effect of independent variable $\mathrm{pH}$ and concentration on yield

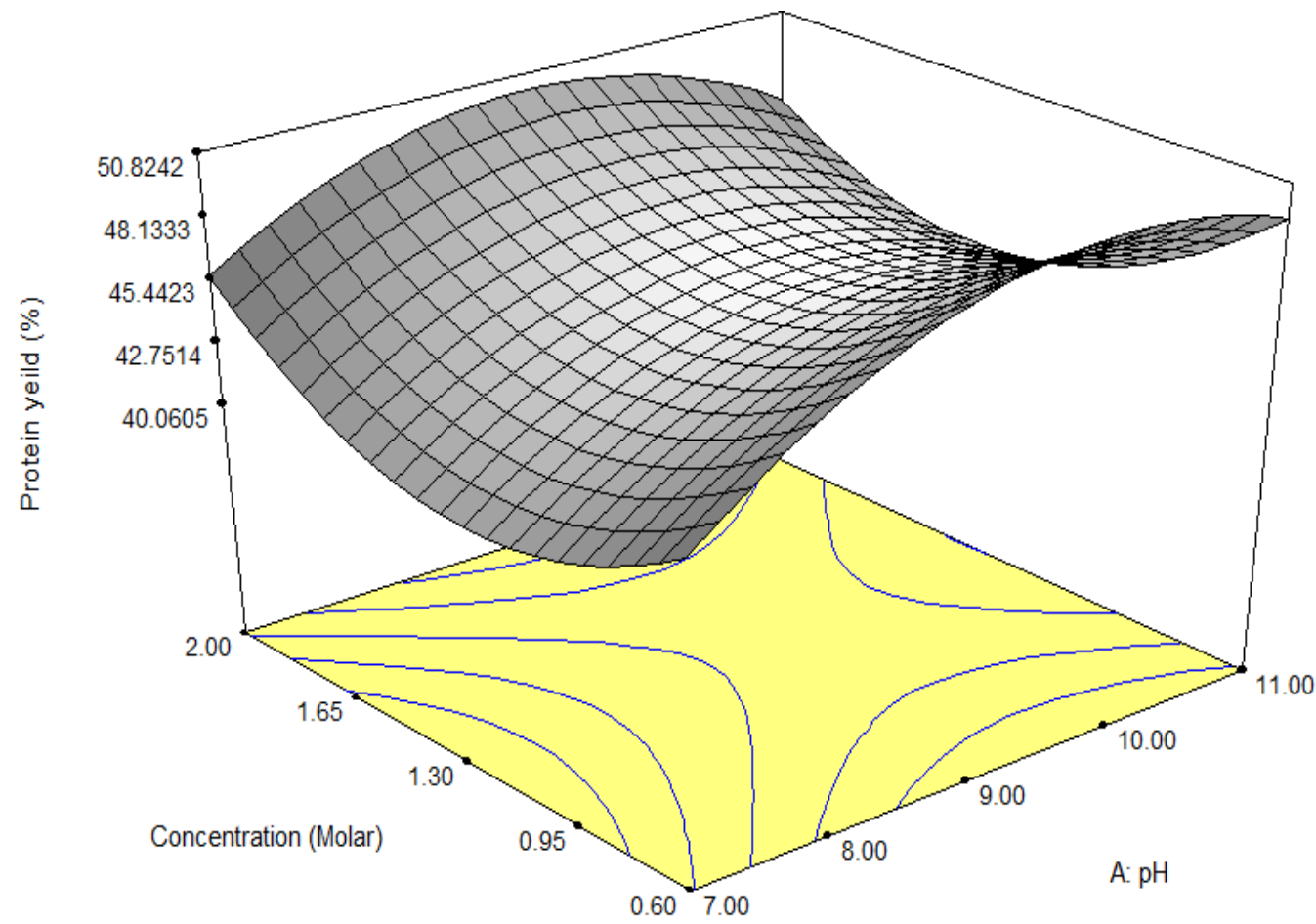


Fig.5 Effect of independent variable $\mathrm{NaOH}$ concentration and flour to solvent ratio on yield

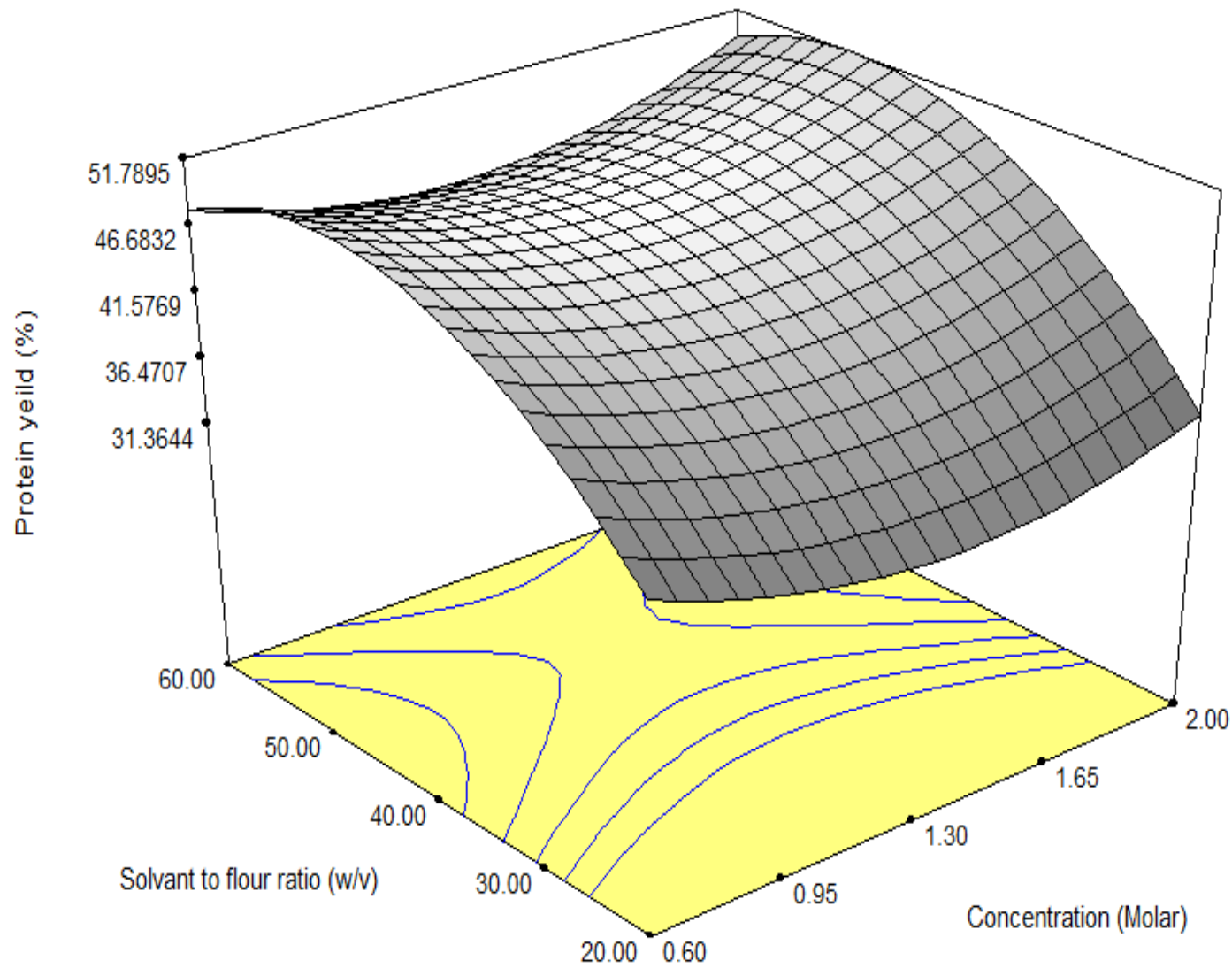

Fig.6 Effect of independent variable $\mathrm{pH}$ and flour to solvent ratio on yield

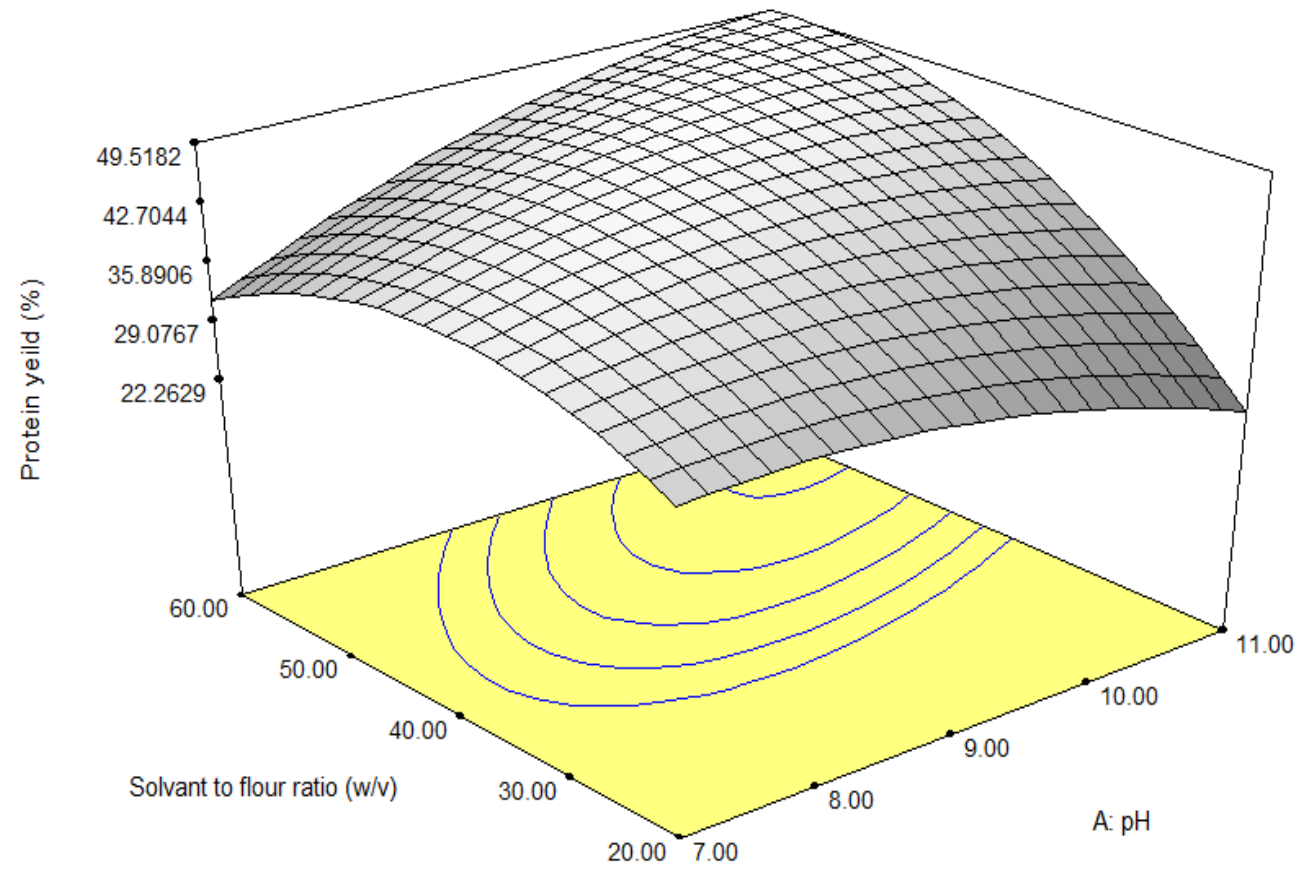


Effect of independent variable $\mathrm{NaOH}$ concentration and flour to solvent ratio on protein content

Coefficient of $\mathrm{NaOH}$ concentration (B) was shown negative effect on protein content. It is observed that increases in $\mathrm{NaOH}$ concentration with decreases in protein content. this study linear terms of $\mathrm{NaOH}$ concentration (B) andflour to solvent ratio (C) had significant and non-significant effect at $5 \%$ level of significance $\quad(\mathrm{p}<0.05)$ respectively.

Quadratic terms of $\mathrm{pH} \quad\left(\mathrm{A}^{2}\right), \quad \mathrm{NaOH}$ concentration $\left(\mathrm{B}^{2}\right)$ and flour to solvent ratio $\left(\mathrm{C}^{2}\right)$ was significant $(\mathrm{p}<0.05)$ having negative quadratic effect, predicting the concave shaped variation on the Protein Content. Coefficient of flour to solvent ratio (C) was positive effective which showed on the protein content (Fig. 3).

Effect of independent variable $\mathrm{pH}$ and concentration on yield

Figure 4 showed the effect of $\mathrm{pH}$ and $\mathrm{NaOH}$ concentration on the protein yield. Coefficient of $\mathrm{pH}$ (A) was shown positive effect on protein yield. It is observed that increases in $\mathrm{pH}$ with increases in protein yield. (Donlaporn Saetaeet et al., 2011) reported that the extraction yields of protein isolated from physic nut seed cake by $\mathrm{pH}$ treatments in a range of 2.0 to 12.0 are shown.

Three dimensional graph was plotted (Figure 4), which depicts protein yield. With increases in $\mathrm{pH}$ up to 9.00 there is an increase in protein yield, but further increase in $\mathrm{pH}$ there is decreases in protein yield. On the other hand as the $\mathrm{NaOH}$ concentration increases up to $1.30 \mathrm{M}$ there is a decrease in protein yield. However as $\mathrm{NaOH}$ concentration increases there will be increases in protein yield was observed.
Effect of independent variable $\mathrm{NaOH}$ concentration and flour to solvent ratio on yield

Figure 5 showed the effect of $\mathrm{NaOH}$ concentration and flour to solvent ratio on the protein yield. Coefficient of $\mathrm{NaOH}$ concentration (B) was shown negative effect on protein yield. It is observed that increases in $\mathrm{NaOH}$ concentration with decrease in protein yield.

Three dimensional graph was plotted (Figure 5), which depicts protein yield. When increases in $\mathrm{NaOH}$ concentration there is decreases protein yield. Increases in flour to solvent ratio up to $40 \%$ there is increases in protein yield. But further increase in flour to solvent ratio there is decreases in protein yield.

It was observed that (Figure 5) maximum protein extracted at $60: 1 \mathrm{v} / \mathrm{w}$ solvent/meal ratio and $2.00 \mathrm{NaOH}$ concentrations. While the $\mathrm{pH}$ is increases also protein yield constantly increases. (Ali Abas Wani et al., 2006) reported that maximum protein could be extracted at 70:1 $\mathrm{v} / \mathrm{w}$ solvent/meal ratio and $1 \_5 \% \mathrm{NaOH}$ concentration.

\section{Effect of independent variable $\mathrm{pH}$ and flour to solvent ratio on yield}

Figure 6 showed the effect of $\mathrm{pH}$ and flour to solvent ratio on the protein yield. Coefficient of $\mathrm{pH}$ (A) was shown positive effect on protein yield. It is observed that increases in $\mathrm{pH}$ with increase in protein yield.

Three dimensional graph was plotted (Figure 6), which depicts protein yield. With increases in $\mathrm{pH}$ up to 9.00 there is an increase in protein yield. But further increase in $\mathrm{pH}$ there is decreases in protein yield. When flour to solvent ratio increases up to $40 \%$ there is increases in protein yield. 


\section{Optimum conditions for experiment}

Optimum extraction conditions for protein isolate was shown Under these criteria, the uncoded optimum operating conditions for development of protein isolate $\mathrm{pH}, \mathrm{NaOH}$ concentration, flour to solvent ratio where 10.40,0.60 (Molar),40.96\%. The responses predicted by the design expart- 6 software for these optimum process conditions resulted protein content $89.35 \%$ and protein yield 51.58. Studies of the extraction of custard apple seed protein isolate could not be traced similar studies using other plant material have been reported.(Wani et al., 2006) studied the extraction of watermelon seed protein and concluded that maximum protein yield was obtained by extracting seed meal with a $\mathrm{NaOH}$ concentration of $1.2 \%$, solvent/meal ratio of 70:1, mixing time of $15 \mathrm{~min}$ and temperature of 40 _C. (Liadakis et al., 1995) worked on protein extraction from tomato seed and found that optimum extraction could be achieved by extracting one part of tomato seed meal with 30 parts of water (w/v) at $\mathrm{pH}$ 11.5 at $50 \_\mathrm{C}$ for $20 \mathrm{~min}$. (Rustom et al., 1991) reported that significant effects of time, temperature, $\mathrm{pH}$ and solvent/meal ratio were found and concluded that optimum extraction were: $\mathrm{pH}$ of 8.0 , time of $30 \mathrm{~min}$; temperature of $50 \_\mathrm{C}$ and solvent/meal ratio of 8.1 . (Mizubuti et al., 2000) state that optimum conditions for protein extraction from pigeon pea were no $\mathrm{NaCl}, \mathrm{pH} 1 / 48.5$ and solvent/meal ratio 1/4 5.1. (Oomah et al., 1994) determined that solvent to meal ratio of $10 \mathrm{l} / \mathrm{kg}, 0.8 \mathrm{~mol} / \mathrm{l}$. $\mathrm{NaCl}$ and $\mathrm{pH} 8.0$ were optimum conditions for extracting protein from flaxseed.

In conclusion, response surface methodology technique proved to be a useful tool in establishing optimum conditions for extracting custard apple seed protein isolate. By conducting preliminary experiments for protein isolate preparation, the approximate range for $\mathrm{pH}, \mathrm{NaOH}$ concentration, and water ratio per $15 \mathrm{~g}$ of flour was decided on the basis of their protein content and protein yield. $\mathrm{pH}$, concentration, water Ratio where 10.40,0.60 (Molar),40.96\%. The responses predicted by the design expart-6 software for these optimum process conditions resulted protein Content 89.35 \% and Protein Yield 51.58. Higher $\mathrm{pH}$ resulted in maximum protein content, protein yield. Higher concentration resulted in maximum protein content, protein yield. Higher water ratio resulted in maximum protein content, protein yield. Optimum solution by numerical optimization obtained was $10.67 \%$ proportion of $\mathrm{pH}, 0.60$ (Molar) Concentration, $42.15 \%$ water ratio respectively. Maximize protein content $89.35 \%$ and protein yield $51.51 \%$ respectively. Optimized protein isolate had protein content $88.10 \%$, protein yield 50.02 $\%$.

\section{References}

AOAC, 1990. Official methods and analysis (25 th edition)'association of different analytical chemists, Washington, P.C. seen introduction to the chemical analysis of foods S. Suzanna Nnelsen, CBS publisher and distributor, New Delhi.

Donlaporn, 2011. Functional Properties of Protein Isolate Obtained from Physic Nut (Jatrophacurcas L.) Seed Cake. Journal of Food Science and Biotechnology, 20(1): 29-37.

Liadakis, G. N., Tzia, C., Oreopoulou, V., \& Thomopoulos, C. D. 1995. Protein isolation from tomato seed meal extraction optimization. Journal of Food Science, 60(3), 477-482.

Lowry, O. H., Rosebrough, N. J., Farr, A. L., \& Randal, R. J. 1951. Protein analysis with Folin-phenol reagent. Journal of Biological Chemistry, 193, 265-275.

Mariod, A.A., Elkheir, S., Idris, Y. M. A. and Matthaus, B. 2010. Annona squamosa 
and C. nilotica seeds, the effect of the extraction method on the oil composition. Journal of American Oil Chemistry Sosacti, 87: 763-769.

Mizubuti, I. Y., Junior, O. B., Souza, L. W. O., Silva, R. S. S. F., \& Ida, E. I. 2000. Response surface methodology for extraction optimization of pigeon pea protein. Food Chemistry, 70, 259-265.

Montgomery, D. C., 2001. Design and analysis of experiments. 416-419.

Morton, J. F., 1987. Fruits of Warm Cimates (Sugar Apple). Florida: Miami, FL.

Morton, J., 1987. Cherimoya. In: Fruits of warm climates, Julia, F. (Ed.). Morton, Miami, Fl., pp: 65-69.I.A. Amoo, A.E. Emenike and V.O.E. Akpambang, 2008.

Nakai, S., Li-Chen, E. C. Y., \& Dou, J. 2006. Experimental design and response surface methodology. In S. Sablani, A. Datta, M. S. Rahman, \& A. Mujumdar.(Eds.), Handbook of food and bioprocess modeling techniques, Vol. 1 (pp. 293- 323). Boca Raton: CRC Press.

Nyam, K.L., and Tan, C.P., 2009. Physicochemical properties and bioactive compounds of selected seed oils. Journal of Food Science and Techmology, 42(8): 1396-1403.

Oomah, B. D., Mazza, G., \& Cui, W. 1994.
Optimization of protein extraction from flaxseed meal. Food Research International, 27, 355-361.

Quanhang, L., \& Caili, F. 2005. Application of response surface methodology for extraction of germinant pumpkin seeds protein. Food Chemistry, 92,701-706

Rustom, I. Y. S., Lopez-Leiva, M. H., \& Nair, B. M. 1991. Optimization of extraction of peanut proteins with water by response surface methodology. Journal of Food Science, 56, 1660-1663.

Sathe, S. K., Deshpande S. and Salunkhe, D. K. 1982. Functional Properties of Lupin Seed (Lupinus mutabilis) Proteins and Protein Concentrates. Journal of Food Science 47(2): 491-497.

Sathe, S. K., Deshpande, S. S. and Salunkhe, D. K. 1982. Functional properties of winged bean (Psophocarpus tetragonolobus, L.) proteins. Journal of Food Science, 47: 503-508.

Wani, A. A., Sogi, D. S., Grover, L. and Saxena, D. C. 2006. To determine Effect of Temperature, Alkali Concentration, Mixing Time and Meal/Solvent Ratio on the Extraction of Watermelon Seed Protien. Response surface approach. Biosystems Engineering, 94(1): 67-73.

\section{How to cite this article:}

Vaidya, A.M., D.C. Saxena and Somani, V.B. 2017. Response Surface Methodology for Optimization of Protein Isolate Preparation from Custard Apple Seed Flour (Annona squmosa). Int.J.Curr.Microbiol.App.Sci. 6(9): 3079-3089. doi: https://doi.org/10.20546/ijcmas.2017.609.379 